\title{
Roads leading to the library \\ The experience of Ukraine in attracting freshmen to the university library
}

$\mathbf{T}$ raditionally, university libraries are associated among students as a place for reading, learning, and research. However, when serving freshmen, it is necessary to create an atmosphere of trust in the library between librarians and students. "When the library acts as a welcoming and lively host, engaging the community in discourse and the enjoyment of the life of the mind, the community perception of the role of the library on campus begins to change. The library becomes a true cultural center and an agent in community building, and library staff and programs become engaged with the community in more and different ways."

Various projects are developed by university libraries to establish contacts with undergraduate students. Often these are

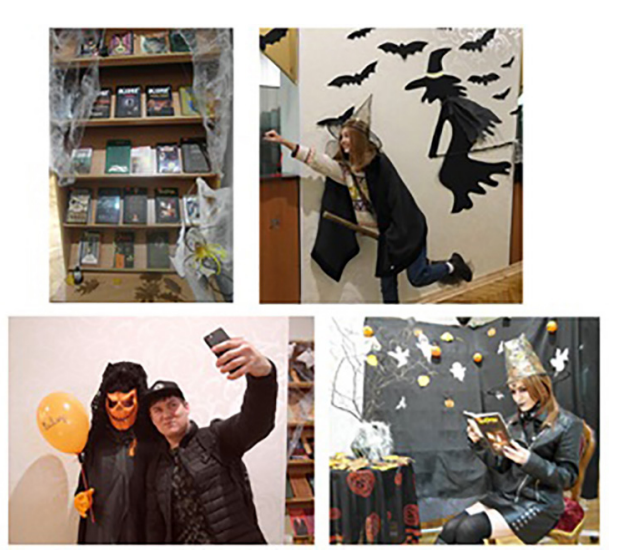

Halloween 2018, students are photographed in the library. $\odot K N U C A$ Libraries

\section{Reading in Ukraine}

The library of the Kyiv National University of Culture and Arts is an important information and cultural center of the university. Promotion of books, holding book exhibitions, and presentations of scientific publications of university teachers are important tasks of the library. Meetings with modern writers within the library book club, \#GalaSlovo, are important elements of communication, excellent projects for students to get acquainted with new books, and receive emotional communication with their authors.

According to the study "Ukrainian Reading and Publishing Data 2018" in the list of the most common types of leisure in Ukraine reading books took fifth place. ${ }^{3}$ Only held in the form of a game, competition, or other motivational event.

The importance and necessity of creating spaces in the academic library for communication, creative meetings, and emotional rest for students are the subject of active discussion. The library is often considered to be an ideal third place for students to interact outside of school. ${ }^{2}$ The purpose of this article is to describe the experience of the library of the Kyiv National University of Culture and Arts (Ukraine) in establishing communication with first-year students. To do this, the library holds thematic events that encourage students to visit the library space and motivate them to read.
$11 \%$ of Ukrainians read daily and $20 \%$ read several times a month. Students read books most often, although $11 \%$ of them do not read books at all, and $20 \%$ read them only a few times a year. A 2019 study found that only $43 \%$ of Ukrainians read books regularly. The share of reading youth aged 18 to 30 was $51 \%$ of respondents. The average Ukrainian reader reads about 9 books a year. In 2017, this figure was

Olena Skachenko is head of the sector at the Scientific Library of the Kyiv National University of Culture and Arts, Ukraine, email: skachenko.nana@gmail.com

(ㅇ) 2021 Olena Skachenko 
7 books. ${ }^{4}$ In the first quarter of 2020, according to a survey conducted by the research agency Info Sapiens, at least one book was read by $73 \%$ of Ukrainians. ${ }^{5}$ The most recognizable contemporary Ukrainian writers are Lina Kostenko, Serhiy Zhadan, and Oksana Zabuzhko.

The library system of Ukraine has 190 university libraries, about 16,000 school libraries, and 15,000 public libraries. ${ }^{6}$ However, in 2018 "only a quarter $(23 \%)$ of the adult population of Ukraine visited a library or bookstore at least once." Reading books taken from the library takes only the third position $(14.8 \%)$, after purchase $(35.2 \%)$ and free download $(20.8 \%){ }^{8}$ These trends

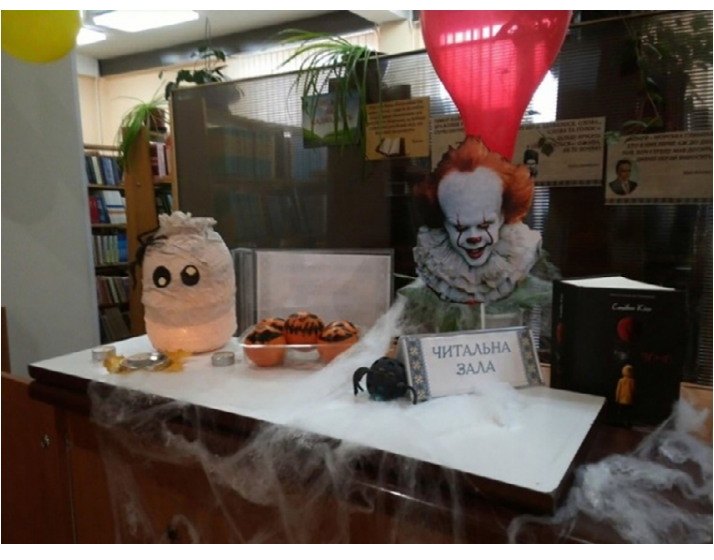

Exhibition of one book: Stephen King It. Photographed by Helen Skachenko. OKNUCA Libraries for Halloween were a popular project to motivate reading and visits to the library space. During the events, the library staff introduced students to the library's resources in a game format. The program for Halloween 2018 was dedicated to the promotion of books from the horror genre. The slogan of the event was Stephen King's phrase "When all else fails, give up and go to the library."

First-year students of the Faculty of Design and Advertising and the Faculty of Information Policy and Cyber Security responded to this call. Librarians decorated the library hall, book exhibitions, and photo areas with the attributes of the holiday (Jack's lamps, ghosts, creative ideas and offer readers new paths that will lead them to the library.

During the event, first-year students learned about the hours of the library, the location of departments and reading rooms, viewed open access book exhibitions, learned about the electronic library, the library's website, and social media pages. To recommend and encourage reading, a list of horror books from the library's collection "Morphology of Horror" was posted on the library's website. All books from the list were accompanied by short annotations by the library staff. Students liked this format to get acquainted with the library space.

In 2019, the library held a Halloween battle "Ghosts in the library." The target audience of the event was first and second-year students of the Faculty of Hotel and Restaurant Business and second-year students of the Faculty of Design. We asked students to come to the meeting in clothing that was in line with the traditions of Halloween. At the beginning of the event, students of the Faculty of Design performed a fashion show in costumes.

\section{Halloween as a form of library advertising and encouragement to read}

From 2018 to 2019, events organized in the library black cats). Mice ran through the bookshelves, spiders hid between the pages, a cat guarded the sweets. Student designers helped to design a photo location "Flight of the Witch to the Library." A special exhibition was dedicated to one book: Stephen King's It.

During the event, first-year students learned about the hours of the library, the location of departments and reading rooms, viewed open access book exhibitions, learned about the electronic library, the library's website, and social media pages. To recommend and encourage reading, a list of horror books from the library's collection "Morphology of Horror" was posted on the library's website. All books from the list were accompanied by short annotations by the library staff. Students liked this format to get acquainted with the library space.

In 2019, the library held a Halloween battle "Ghosts in the library." The target audience of the event was first and second-year students of the Faculty of Hotel and Restaurant Business and secondnd-year students of the Faculty of Design. We asked students to come to the meeting in clothing that was in line with the traditions of Halloween. At the beginning of the event, students of the Faculty of Design performed a fashion show in costumes.

The host of the event was the film hero Joker and Ghosts, who were brawling in the library. To reassure 
the Joker, students performed various tasks related to library work and Halloween traditions in different countries. Among the tasks proposed by the Ghosts were, for example:

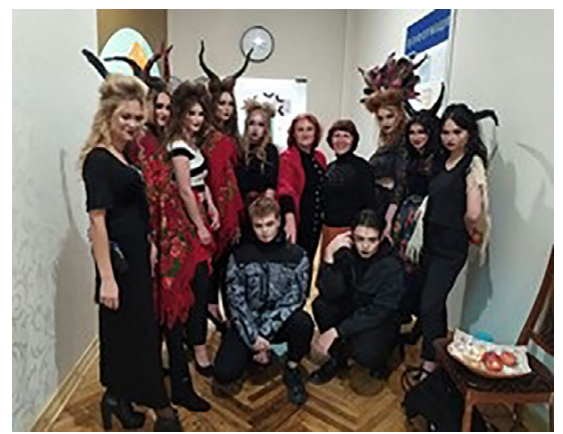

Students participating in the event Halloween - 2019. Photographed by Helen Skachenko. oKNUCA Libraries

- find Stephen King's books in the electronic library catalog,

- find an explanation of the word "horror" in directories,

- name the last book read and recommend it for reading, and

- find the oldest book from the collection of rare editions of the library on the shelves of a book exhibition, etc.

Among the competitions that Joker offered students to perform was the traditional game bobbing for apples. Students demonstrated a modern version of the game when it was necessary to bite an apple attached to a highly raised string. The players kept their hands behind their backs. ${ }^{10}$

In one task, students had to compose proverbs from individual words. For example, the following:

The way to God is difficult, and to hell it is straightforward.

Only witches fly on a broom.

In a quiet swamp, devils

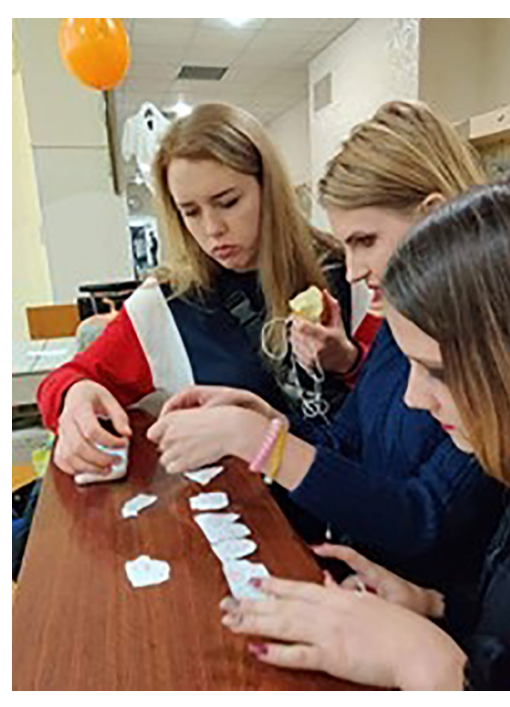

Game task: students compose proverbs from individual words. Photographed by Helen Skachenko. OKNUCA Libraries are found

For Halloween 2020, librarians celebrated with students remotely. With the digital tool Kahoot! we prepared a quiz and invited students from two colleges of the culture of Ukraine: Kalush Vocational
College of Culture and Arts and Sumy Vocational College of Arts and Culture. Eighteen students from two Ukrainian regions, the city of Sumy and the city of Kalush, competed online by answering quiz

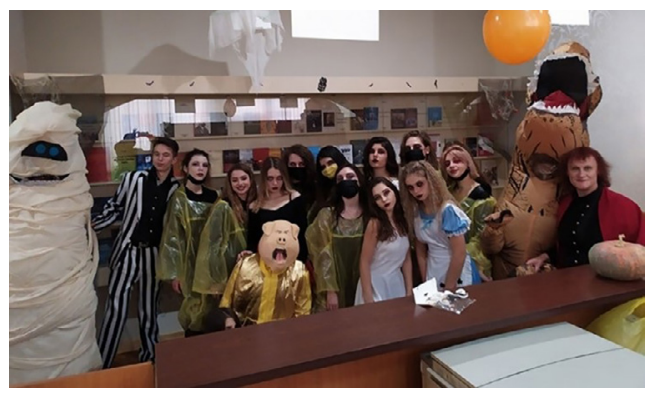

questions concerned the history and traditions of Halloween. ${ }^{11}$ Diplomas were sent to the winners of the quiz by e-mail.

\section{Conclusion}

The activity of the book club, organization of book exhibitions, and presentations of scientific publications of university teachers is an important task of the library. These are the roads that lead new readers to the library of the Kyiv National University of Culture and Arts.

By holding thematic events for first-year students in the library, we are transforming the library space into a place for implementing cultural initiatives and holding intellectual games and creative competitions. After all, as Sam Demas emphasizes, "People continue to come to libraries because they offer security, comfort, and quiet; are free and commercialfree; provide a place to be with other people in a learning/ cultural environment; offer opportunities to learn, search, inquire, and recreate; and afford opportunities for choice and serendipity." 12

By developing a program of events, the library staff creates a free atmosphere for university students, 
which contributes to the formation of a team of like-minded people advertising the library as a place of creative meetings and motivates students to read the books offered at the book exhibition. During the COVID-19 pandemic, we conducted all book promotion events online depriving students, librarians, and book authors of the opportunity to communicate directly. We hope that after the quarantine, various offline meetings and holiday presentations of books in the library will resume and become important channels for the promotion and reading of books.

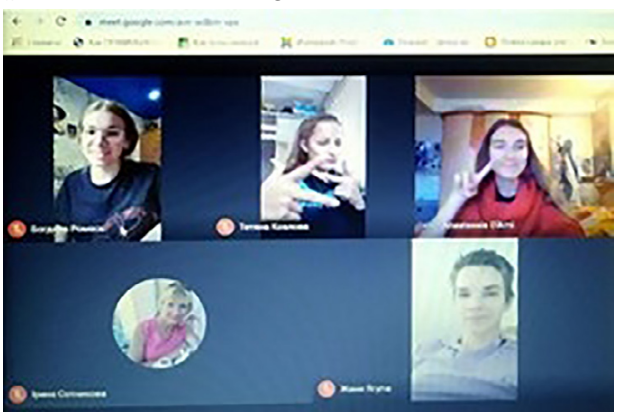

5. $72 \%$ of Ukrainians read books-a new study by Info Sapiens," https://chytomo.com/vukraini-riven-chytannia-zris-do-72-doslidzhenniainfo-sapiens/.

6. Oksana Khmelovskaya, "We predict the future: Publishing houses, printing houses and libraries after the pandemic," https://chytomo.com /prorokuiemo-majbutnie-vydavnytstva-drukarni -j-biblioteky-pislia-pandemii/?fbclid=IwAR0juh -borca8Wygy_Hu8pMnbH6HJGY1PM58vc3rkGBAi7Jt9AYDUpdgdhQ (accessed November 21, 2020).

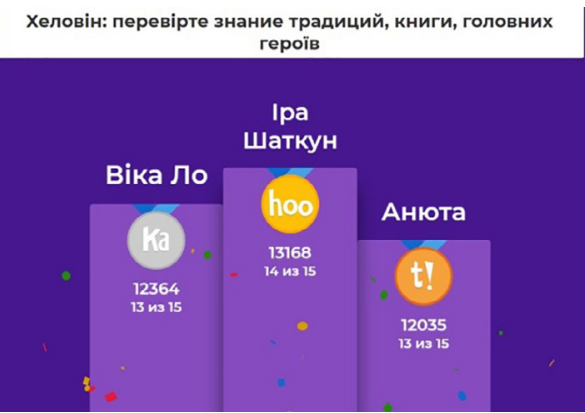

Participants of the online game Kahoot! and a podium of game-winners. Screenshot by Helen Skachenko. @KNUCA Libraries

We hope that the experience of the library at Kyiv National University of Culture and Arts in helping students get acquainted with the library and motivating them to read through our Halloween event will be useful for other libraries.

\section{Notes}

1. Sam Demas, "From the ashes of Alexandria: What's happening in the college library?" in Library as Place: Rethinking Roles, Rethinking Space (Washington, DC: Council on Library and Information Resources, 2005): 25-40.

2. Lisa Waxman, Stephanie Clemons, Jim Banning, and David McKelfresh, "The library as place: Providing opportunities for socialization, relaxation, and restoration," New Library World, 108(9/10) (2007): 424-434.

3. "Reading in Ukraine," Ukrainian Reading and Publishing Data 2018, http://data.chytomo.com/ chytannya-v-ukrayini/ (accessed November 21, 2020).

4. "Books in the past: More than half of Ukrainians do not read literature," http://phm. gov.ua/?p=77898 (accessed November 21, 2020).
7. Katerina Churilova, "Most Ukrainians have not read a single book in a year and have not gone to the theater or cinema," https://zaxid.net/bilshist _ukrayintsiv_za_rik_ne_prochitali_zhodnoyi _knizhki_ta_ne_hodili_v_teatr_i_kino_ n1477719 (accessed November 21, 2020).

8. "Reading in Ukraine," Ukrainian Reading and Publishing Data 2018, http://data.chytomo.com/ chytannya-v-ukrayini/ (accessed November 21, 2020).

9. KNUCALibrary, "Halloween battlein thelibrary," http://lib.knukim.edu.ua/khellovin-batl-u-biblioteci/.

10.Olena Skachenko, "Halloween_Library KNUCA" by Helena on Genially, https://view.genial. ly/5f8d6e8dcc6b7a0d385d9e76/presentation-halloweenlibrary-knuca (accessed November 21, 2020).

11. KNUCA Library, "Meet video conferencing: Opportunities for libraries," http://lib.knukim.edu.ua/videokonferencii-meet-mozhlivosti -dlya-bi/ (accessed November 21, 2020).

12. Sam Demas, "From the ashes of Alexandria: What's happening in the college library?" in Library as Place: Rethinking Roles, Rethinking Space (Washington, D.C.: Council on Library and Information Resources, 2005): 25-40. z2 